\title{
GROWING SPINACH (Spinacia oleracea L.) IN A FLOATING SYSTEM WITH DIFFERENT CONCENTRATIONS OF NUTRIENT SOLUTION
}

\author{
ÖZTEKIN, G. B. ${ }^{1 *}-$ ULUDAĞ, T. $^{2}-$ TÜZEL, Y. ${ }^{1}$ \\ ${ }^{I}$ Department of Horticulture, Faculty of Agriculture, Ege University, Bornova-Izmir, Turkey \\ ${ }^{2}$ Department of Horticultural Science, Graduate School of Natural and Applied Sciences, Ege \\ University, Bornova-Izmir, Turkey \\ *Corresponding author \\ e-mail: golgen.oztekin@ege.edu.tr; phone:+90-232-3112577; fax: +90-232-3881865
}

(Received $26^{\text {th }}$ Feb 2018; accepted 24 $4^{\text {th }}$ May 2018)

\begin{abstract}
This study was conducted in a greenhouse in Izmir/Turkey during the winter-early spring of 2016-2017, on spinach grown in the floating water culture system. Cultivation was carried out in aerated nutrient solutions on seedling trays, and peat was used as germination and rooting medium. Each seed was inserted to each hole $(17 \mathrm{cc})$ in trays with 210 cells $\left(957\right.$ plant $\left.\mathrm{m}^{-2}\right)$. Following germination in the germination chamber, trays were moved to climate controlled greenhouse. After emergence, the seedlings were transferred to water culture on 07.12.2016 and 10.03.2017 for the $1^{\text {st }}$ and $2^{\text {nd }}$ period, respectively. The nutrient solution was applied as "full dose" (mg L-1. N 150, P 50, K 150, Ca 150, Mg 50, Fe 5.0, Mn 0.50 , Zn 0.05, B 0.50, Cu 0.03, Mo 0.02), "half dose" (with macro elements reduced by 50\%) and "without nutrients" (water). Plants as baby leaves were harvested 3 times in both periods. Results showed that plant growth, yield, quality, and water consumption vary depending on the concentration of nutrient solution as well as the temperature during the growing season. Especially in the $2^{\text {nd }}$ period when the temperatures were higher, plant water consumption and yield increase and earliness were achieved. It was observed that as the concentration of nutrient solution decreased, vitamin $\mathrm{C}$, leaf $\mathrm{Ca}$ content and $\mathrm{pH}$ value of the nutrient solution increased while leaf N, P, K and Fe contents, EC value of the nutrient solution, leaf nitrate content, yield and plant biomass decreased. There was no statistical difference between full and half dose applications in many measured parameters. It is concluded that spinach can be grown as a baby leaf in a floating water culture and that in addition to reducing nitrate content, half-dose application may be preferred in terms of yield and water consumption, and production should be done during early spring season in greenhouse conditions for high yield and quality.
\end{abstract}

Keywords: water culture, growing period, dose, yield, nitrate, vitamin $C$

\section{Introduction}

In world markets, the demand and interest in clean and minimal processed food stuffs is continuously increasing with each passing day. Life styles of people on the other hand have evolved into a practical and a swift style. Employed or working women are able to spend less time in kitchens; therefore, they mostly prefer freshly consumed, instant, practical and healthy foods. Edible leaf vegetables are quite rich in vitamins and antioxidants (Yadav et al., 2013) and they are commonly used in salads and several other dishes. Thus, they are quite preferred by the consumers. These vegetables should be cleaned right after the harvest and such a cleaning process results in serious waste of time and water. In recent years, soilless culture, especially hydroponic culture, have become popular to facilitate the cleaning of edible leaf vegetables and to serve them for consumption with a minimum processing (Nicola et al., 2007).

Among the hydroponic culture systems, static solution culture is the oldest and easiest soilless culture technique. In today's modified version of the technique, plants 
are placed over styrofoam platforms freely floating over the nutrient solution and thus the method is called as "floating water culture" (Morgan, 1999; Gül, 2008). The system is composed of a basin containing nutrient solution, a light-weight material able to float over the nutrient solution to hold the seeds or seedlings and an air pump for aeration of the system.

Floating water culture was designed and developed by Arizona University in 1980; couple years later, was used in vegetable culture commercially in Florida (Resh, 1998). The method is commonly used in seedling production (Carrasco et al., 2003; Bilalis et al., 2010) and regular or miniature vegetable production (Fontana et al., 2010; Carrasco et al., 2011). The system today is widely used in unheated greenhouses of Mediterranean countries with minimum control of climate parameters for the same purposes (Duyar and Kılıç, 2016).

The advantages of floating hydroponic systems are specified as: easy system construction, economic production, low labor costs because of automation systems, rapid plant growth, homogeneous products, high and quality yields, clean products, greater number of plants per unit area, easy harvest, optimized fertilizer and water use, minimum evaporative losses, environment-friendly production and easy adaptation to small production areas (Fernandez et al., 2008; Franco et al., 2011; Tomasi et al., 2015). On the other hand, aeration demands of nutrient solution and resultant electricity requirement, changes (increase or decrease) in temperature of nutrient solution based on seasons are considered as potential disadvantages of the floating systems (Nicola et al., 2005; Rodriguez Hidalgo et al., 2010). Despite all these disadvantages, floating systems are largely preferred for production of various vegetable species since in soil plants are exposed to several soil-borne diseases, leaves are contaminated with soils resulting in leaf losses. The vegetables produced in soil cultures should also be cleaned and washed through before to serve them to the markets. When the leaves are washed and served to markets, leaf heat ups and resultant losses are experienced. On the other hand in floating hydroponic cultures, contamination with soil is totally eliminated, thus significant savings achieved in labor and water since post-harvest washing is not required.

Besides clean production, low nitrate contents are desired in directly consumed edible leaf vegetables. Excessive nitrogen uptake (excessive fertilization) or inhibition of nitrogen transformation into protein by some environmental factors result in nitrogen accumulation throughout the plant growth stages (Kara, 1993). A small part of nitrogen taken through nutrition is reduced to nitrite by the mouth bacteria and conveyed to the stomach. When the $\mathrm{pH}$ level of the stomach got above 5.5, nitrate is converted into hazardous nitrite ions through bacterial nitrate reductase activity. Nitrite then interacts with hemoglobin and result is methemoglobin formation; hemoglobin $\mathrm{Fe}^{+2}$ then oxidized to $\mathrm{Fe}^{+3}$ and ultimately blood oxygen carrying function is reduced or inhibited. Then the case is evolved into a hazardous disease for kids (methemoglobinaemia, bluebaby syndrome, cyanotic, cyanosis). Nitrite has various other negative impacts on human health, for instance it reacts with secondary amines and result in formation of carcinogen, mutagen and teratogen nitrosamines (Tannenbaum and Correa, 1985; Kara, 1993; Özdestan and Üren, 2010).

Existence of nitrate problems in leaf edible vegetables let the researchers mostly focus on nitrate in these species. Hydroponic researches revealed that micro element concentrations of the nutrient solution could be reduced (Cocetta et al., 2007; Duyar and K1lıç, 2016), nutrient solution could be diluted (Vernieri et al., 2005), plants could be stayed in water for couple days before the harvest (Gonnella et al., 2004; Jakse et al., 
2013), $\mathrm{NO}_{3}-\mathrm{N}$ could be withdrawn/replaced with $\mathrm{Cl}, \mathrm{SO}_{4}$ and $\mathrm{NH}_{4}$ (Van Der Boon et al., 1990) all to reduce nitrate contents of the vegetables. These researches also revealed that floating culture could be used as an economic and environment-friendly culture technique.

Hoagland nutrient solution (Hogland and Arnon, 1950) is commonly used in floating culture researches undertaken for leaf edible vegetables (Vernieri et al., 2005; Cocetta et al., 2007; Alberici et al., 2008; Duyar and Kılıç, 2016). Although Hoagland nutrient solution supply quite quality nutrition for leaf edible vegetables harvested in short periods, it is known that this nutrient solution was primarily developed for tomato to get high yield in long growing periods. Thus in this case, potential use and efficiency of Hoagland nutrient solution in leaf edible vegetables are arguable issues. It was also considered that element contents of Hoagland prescription was higher than the prescriptions adapted for leaf edible vegetables and had quite much nutrient contents in post-harvest residues with potential environmental pollution (Alberici et al., 2008).

Spinach could be an alternative crop in greenhouses since it allows for multiple short-duration production cycles and a much faster economic return (Brandenberger et al., 2007). Besides, spinach is a vegetable with a high nutritional value (Ko et al., 2014) The present study was conducted to investigate the potential use of floating hydroponic culture for spinach production in unheated greenhouses in winter-early spring periods (1). Since there are not any species-specific nutrient solution prescription, availability of a nutrient solution other than Hoagland nutrient solution (winter nutrient solution prepared for lettuce) for spinach culture was also investigated in this study (2). Effects of dilution of macro element concentrations of the nutrient solution on plant growth and development, yield, quality and water consumption were also investigated in this study (3). In this way, high yield and quality spinach culture with floating hydroponic culture and proper nutrient prescription in proper periods in unheated greenhouses under Mediterranean climate conditions was assessed.

\section{Materials and Methods}

Experiments were conducted in vegetable greenhouse of Horticulture Department of Ege University Agricultural Faculty (Bornova-İzmir/Turkey, 38²7'17.03' 'N, $27^{\circ} 14^{\prime} 17.71$ '’ E) in winter-early spring growing periods of 2016-2017.

'Aletta $F_{1}$ ' (Küçükçiftlik Seed Co., Balıkesir/Turkey) spinach (Spinacia oleracea L.) cultivar was used as the plant material of the experiments. Styrofoam seedling trays $(66.5 \times 33.5 \times 4.9 \mathrm{~cm}$, with $17 \mathrm{cc}, 210$ cells) were used as the growing place. Peat (Klassman TS1) was used as the substrate for seed germination.

Seeds were sown in two successive periods on 24.11.2016 in the $1^{\text {st }}$ period (winter) and on 21.02.2017 in the $2^{\text {nd }}$ period (early spring) into the peat-filled seedling trays as to have one seed per cell $\left(1.5 \mathrm{~g}\right.$ seed per $\left.\mathrm{m}^{2}\right)$. Excess plantlets were thinned after emergence. There were 957 plants per $\mathrm{m}^{2}$. Following the seed sowing, growing medium were moistened, covered with stretch films and placed into germination chambers. Seedling trays were kept in germination chamber (dark, day/night $18-20^{\circ} \mathrm{C}, 80 \%$ humidity) for 4 days. They were then placed into seedling adaptation greenhouse and kept there until they had 1-2 true leaves. During this period, seedlings were irrigated with boom irrigation system of the greenhouse.

Hydroponic cultures were formed in $80 \times 44 \times 19 \mathrm{~cm}$ (52 liters) plastic basins (Fig. 1). PE-transparent air hoses were used to aerate nutrient solution. One end of the hose was 
connected to air compressor and the end was closed. The hose passed through culture basins and outlets with air stones were placed for each basin. Mini valves were used to adjust aeration rates (8.0-8.5 $\left.\mathrm{mg} \mathrm{L}^{-1}\right)$. Compressor electricity was supplied with a timer; the timer was set as 30:30 minutes start:stop mode for 24 hours.

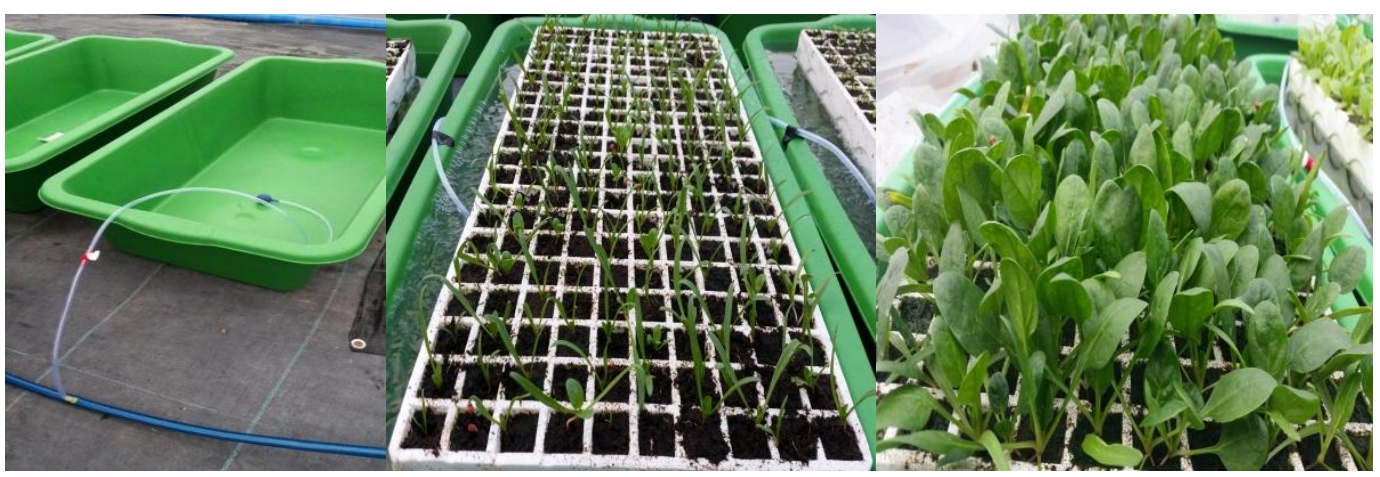

Figure 1. View of floating cultures in plastic basins

The plant nutrient solution proposed by Gül (2008) for winter lettuce ( $\mathrm{mg} \mathrm{L}^{-1}: \mathrm{N} 150$, P 50, K 150, Ca 150, Mg 50, Fe 5.0, Mn 0.50, Zn 0.05, B 0.50, Cu 0.03, Mo 0.02) was used in this study. The recommended prescription was accepted as "full dose" (complete nutrient solution) and this full dose was compared with "half dose" with $50 \%$ reduced macro nutrients. Electrical conductivity (EC) of prepared nutrient solution was 1.6-1.8 dS m $\mathrm{d}^{-1}$ in full dose; $1.2-1.3 \mathrm{dS} \mathrm{m}^{-1}$ in half dose while $\mathrm{pH}$ was 5.5-6.0 and 6.3-6.5, respectively. "Water" without any fertilizers was another treatment in order to test if irrigation water alone could be used due to short crop cycle. The content of irrigation water was as follows: N 7, P 1.10, K 1.19, Ca 127.4, Mg 45.8, Na 29.8, Cl 52.0, Fe 1.43, Mn 0.88, Zn 0.38, Cu $0.11 \mathrm{mg} \mathrm{L}^{-1}$; EC $0.93 \mathrm{dS} \mathrm{m}{ }^{-1}$; $\mathrm{pH} 7.35$. Each basin was filled with nutrient solution treatments or water $(40 \mathrm{~L})$. Seedlings were transplanted to water culture on 07.12 .2016 for the $1^{\text {st }}$ period and on 10.03 .2017 for the $2^{\text {nd }}$ period when they had 2 true leaves. Plants were kept in hydroponic culture for 59 days in the $1^{\text {st }}$ period and for 38 days in the $2^{\text {nd }}$ period. Throughout these periods, depleted nutrient solution or water was resupplied weekly and EC and $\mathrm{pH}$ adjustments were made in each time. Productions were terminated on 07.02.2017 for the $1^{\text {st }}$ period and on 17.04.2017 for the $2^{\text {nd }}$ period.

Greenhouse indoor temperature, relative humidity and solar radiation values were measured with sensors (Delta-T Devices) and recorded with data loggers (Delta-T Devices; GP1 and DL3000). Manual thermometers were used to measure the temperature of nutrient solution. Temperatures $\left({ }^{\circ} \mathrm{C}\right)$ of the nutrient solutions and water treatments were measured in the morning, noon and evening of each day.

Harvests were performed when the outer, older leaves reached to a length of 10-15 $\mathrm{cm}$. When the plants reached to harvest maturity, 10 homogeneous plants were selected from each replication and plant growth parameters were measured. Root lengths (from top to bottom) were measured with a tape meter and average root length was expressed in $\mathrm{cm}$. The distance between the starting place of the roots and the tip of plant leaves was measured again with a tape meter $(\mathrm{cm})$ and the values were used as plant height. Leaf fresh weight of the plants was measured with a precise balance. Leaves were dried 
at $65{ }^{\circ} \mathrm{C}$ until a constant weight and weighted again to get leaf dry weights. The values were used as fresh (FW) and dry (DW) weights (g) and dry matter (\%).

The first harvest was performed 33 days after transplantation to hydroponic culture in the $1^{\text {st }}$ period and 20 days after transplantation in the $2^{\text {nd }}$ period. A total of three harvests were performed on 10.01.2017, 27.01.2017 and 07.02.2017 in the $1^{\text {st }}$ period and on 30.03.2017, 07.04.2017 and 17.04.2017 in the $2^{\text {nd }}$ period. In each harvest, plants were cut above the growing tip to allow plants to regrow new leaves. Harvests were terminated after the $3^{\text {rd }}$ harvest because of the losses in leaf quality. From the first to last harvest, plants harvested from each replication were weighted separately and yields per harvest $(\mathrm{g})$ and total yields $\left(\mathrm{g} \mathrm{m}^{-2}\right)$ were calculated.

From each replicates, 10 plants were randomly selected to determine leaf total chlorophyll content ( $\mathrm{mg} \mathrm{g}^{-1}$ ) (Arnon, 1949), nitrate content $\left(\mathrm{mg} \mathrm{kg}^{-1}\right.$ ) (Cataldo et al., 1975) and vitamin C content (mg $100 \mathrm{~g}^{-1} \mathrm{FW}$ ) (Pearson, 1970) spectrophotometrically.

Plant samples taken from the first harvest were separated as roots and upper sections and dried at $65^{\circ} \mathrm{C}$. Dried samples were than ground and passed to sieves and subjected to $\mathrm{N}, \mathrm{P}, \mathrm{K}, \mathrm{Ca}, \mathrm{Mg}$ and $\mathrm{Fe}$ element analyses. $\mathrm{P}$ content of wet digested samples was determined colorimetrically with Vanadomolibdophosphoric yellow color method; $\mathrm{K}$ and $\mathrm{Ca}$ contents were determined with a flame photometer; $\mathrm{Mg}$ and Fe readings were performed in an atomic absorption spectrophotometer. Total $\mathrm{N}$ was determined with modified Kjeldahl method. Results were expressed as \% dry matter and $\mathrm{mg} \mathrm{kg}^{-1} \mathrm{DW}$ (Kacar and İnal, 2008).

Plant water consumption ( $\mathrm{L} \mathrm{plant}^{-1}$ ) was calculated using the following Equation 1:

$$
\text { Plant water consumption }=\frac{\text { applied nutrient solution-drainage solution }}{\text { number of plant }}
$$

Nutrient solution and water samples were taken from the basins twice a week and EC and $\mathrm{pH}$ of the samples were measured with a portable $\mathrm{EC}$ and $\mathrm{pH}$ meter.

In the present research, 105 plants were used per replicate. Experiments were conducted in randomized plots experimental design with 4 replications and two factors (periods - $1^{\text {st }}$ and $2^{\text {nd }}$ period; nutrient solution concentrations - full dose, half dose and water without fertilizer). Resultant data were subjected to variance analysis with JMP (version 5.0.1) statistical software. Tukey's test was used to compare treatment means. $\mathrm{F}$ test was used to specify significance levels (ns: nonsignificant, *: significant at $0.01<\mathrm{P} \leq 0.05$ and $* *$ : significant at $\mathrm{P} \leq 0.01)$.

\section{Results}

\section{Climate data}

Average greenhouse indoor temperatures and relative humidity values were $11.3^{\circ} \mathrm{C}$ and $72.5 \%$ in the $1^{\text {st }}$ period, $19.8^{\circ} \mathrm{C}$ and $71.1 \%$ in the $2^{\text {nd }}$ period, respectively. Solar radiation value was $5.55 \mathrm{MJ} \mathrm{m}^{-2} \mathrm{day}^{-1}$ in the $1^{\text {st }}$ period and $10.64 \mathrm{MJ} \mathrm{m}^{-2} \mathrm{day}^{-1}$ in the $2^{\text {nd }}$ period.

Nutrient solution temperatures varied between 3.5 and $32.0^{\circ} \mathrm{C}$ (average $10.7^{\circ} \mathrm{C}$ ) in the $1^{\text {st }}$ period and between 9.2 and $37.5^{\circ} \mathrm{C}$ (average $20.0^{\circ} \mathrm{C}$ ) in the $2^{\text {nd }}$ period. 


\section{Plant growth and biomass values}

The effects of growing periods on plant height, root length, leaf fresh and dry weights and dry matter contents, root dry weight and dry matter contents were found significant. All these parameters had greater values in the $2^{\text {nd }}$ period than in the $1^{\text {st }}$ period. In the $2^{\text {nd }}$ period, plant heights increased by $27.1 \%$, root lengths increased by $17.5 \%$. As compared to the $1^{\text {st }}$ period, plant fresh and dry weights increased respectively by 1.9 and 2.6 folds in the $2^{\text {nd }}$ period (Table 1$)$.

Nutrient solution concentration had significant effects on plant heights, root lengths, leaf fresh and dry weights and leaf dry matter. There were not significant differences in these measured parameters of full and half doses but water-treated plants had the lowest values. However, the greatest root length was obtained from water treatments (Table 1).

Period $\mathrm{x}$ nutrient solution concentration interaction had significant effects on plant height, root length, leaf biomass and root dry matter. The highest plant heights, leaf fresh and dry weights and leaf and root dry matters were higher in the $2^{\text {nd }}$ period (early spring) in full and half dose treatments. The lowest measurements were obtained from water treatment excluding root lengths (Table 1).

Table 1. Effects of different season and nutrient solution concentration on plant growth and biomass

\begin{tabular}{|c|c|c|c|c|c|c|c|c|c|}
\hline \multirow[b]{2}{*}{ Period } & \multirow[b]{2}{*}{$\begin{array}{l}\text { Nutrient } \\
\text { solution } \\
\text { concentration }\end{array}$} & \multirow[b]{2}{*}{$\begin{array}{c}\text { Plant } \\
\text { height } \\
\text { (cm) }\end{array}$} & \multirow[b]{2}{*}{$\begin{array}{l}\text { Root } \\
\text { length } \\
\text { (cm) }\end{array}$} & \multicolumn{3}{|c|}{ Leaf } & \multicolumn{3}{|c|}{ Root } \\
\hline & & & & $\begin{array}{c}\text { Fresh } \\
\text { weight } \\
(\mathrm{g}) \\
\end{array}$ & $\begin{array}{c}\text { Dry } \\
\text { weight } \\
\text { (g) }\end{array}$ & $\begin{array}{c}\text { Dry } \\
\text { matter } \\
(\%)\end{array}$ & $\begin{array}{c}\text { Fresh } \\
\text { weight } \\
\text { (g) }\end{array}$ & $\begin{array}{c}\text { Dry } \\
\text { weight } \\
(\mathrm{g})\end{array}$ & $\begin{array}{c}\text { Dry } \\
\text { matter } \\
(\%)\end{array}$ \\
\hline \multirow{5}{*}{$\begin{array}{l}1^{\text {st }} \\
2^{\text {nd }}\end{array}$} & & $10.7 \mathrm{~b}$ & $27.5 \mathrm{~b}$ & $2.67 \mathrm{~b}$ & $0.23 \mathrm{~b}$ & $8.8 \mathrm{~b}$ & 0.54 & $0.035 \mathrm{~b}$ & $5.8 \mathrm{~b}$ \\
\hline & & $13.6 \mathrm{a}$ & $32.3 \mathrm{a}$ & $5.66 \mathrm{a}$ & $0.64 \mathrm{a}$ & $12.8 \mathrm{a}$ & 0.57 & $0.049 \mathrm{a}$ & $8.5 \mathrm{a}$ \\
\hline & Full dose & $13.8 \mathrm{a}$ & $26.5 \mathrm{~b}$ & $4.96 \mathrm{a}$ & $0.52 \mathrm{a}$ & $10.1 \mathrm{~b}$ & 0.60 & 0.046 & 7.5 \\
\hline & Half dose & $13.1 \mathrm{a}$ & $29.0 \mathrm{~b}$ & $4.85 \mathrm{a}$ & $0.48 \mathrm{a}$ & $9.6 \mathrm{~b}$ & 0.55 & 0.042 & 6.9 \\
\hline & Water & $6.6 \mathrm{~b}$ & $34.2 \mathrm{a}$ & $1.20 \mathrm{~b}$ & $0.17 \mathrm{~b}$ & $14.6 \mathrm{a}$ & 0.51 & 0.038 & 7.2 \\
\hline \multirow[t]{3}{*}{$1^{\mathrm{st}}$} & Full dose & $11.5 \mathrm{ab}$ & $24.3 \mathrm{c}$ & $3.05 \mathrm{~b}$ & $0.26 \mathrm{~b}$ & $8.4 \mathrm{~b}$ & 0.62 & 0.037 & $5.6 \mathrm{~cd}$ \\
\hline & Half dose & $11.2 \mathrm{ab}$ & $25.3 \mathrm{bc}$ & $2.89 \mathrm{~b}$ & $0.24 \mathrm{~b}$ & $8.2 \mathrm{~b}$ & 0.51 & 0.035 & $5.3 \mathrm{~d}$ \\
\hline & Water & $7.9 \mathrm{~b}$ & $33.1 \mathrm{ab}$ & $1.47 \mathrm{~b}$ & $0.16 \mathrm{~b}$ & $10.8 \mathrm{~b}$ & 0.47 & 0.032 & $6.7 \mathrm{bcd}$ \\
\hline \multirow[t]{3}{*}{$2^{\text {nd }}$} & Full dose & $16.2 \mathrm{a}$ & $28.7 \mathrm{abc}$ & $6.87 \mathrm{a}$ & $0.78 \mathrm{a}$ & $11.9 \mathrm{~b}$ & 0.57 & 0.054 & $9.3 \mathrm{a}$ \\
\hline & Half dose & $15.1 \mathrm{a}$ & $32.8 \mathrm{ab}$ & $6.82 \mathrm{a}$ & $0.72 \mathrm{a}$ & $10.9 \mathrm{~b}$ & 0.58 & 0.049 & $8.4 \mathrm{ab}$ \\
\hline & Water & $5.3 \mathrm{~b}$ & $35.4 \mathrm{a}$ & $0.94 \mathrm{~b}$ & $0.17 \mathrm{~b}$ & $18.4 \mathrm{a}$ & 0.55 & 0.044 & $7.6 \mathrm{abc}$ \\
\hline Analysis & Period & $*$ & $*$ & $* *$ & $* *$ & $* *$ & $n s$ & $*$ & $* *$ \\
\hline of & Concentration & $* *$ & $*$ & $* *$ & $* *$ & $* *$ & $n s$ & $n s$ & $n s$ \\
\hline variance & Period $x$ Concentration & $*$ & $*$ & $*$ & $* *$ & $*$ & $n s$ & $n s$ & $*$ \\
\hline
\end{tabular}

Means within each column followed by the same letters are not significantly different according to Tukey test. $\mathrm{ns}, *$ and $* *$ : nonsignificant, significant at $0.01<P \leq 0.05$ and $P \leq 0.01$, respectively.

\section{Yield}

Effects of the period, nutrient solution concentration and period $\mathrm{x}$ concentration interaction on yields values were found to be significant (Table 2, Fig. 2). The highest yield values were obtained from the $1^{\text {st }}$ harvest. As compared to the $1^{\text {st }}$ harvest, yield values in the $2^{\text {nd }}$ and $3^{\text {rd }}$ harvests respectively decreased by $41.5 \%$ and $50.3 \%$ in the $1^{\text {st }}$ period and by $72.1 \%$ and $52.3 \%$ in the $2^{\text {nd }}$ period.

In all three harvests, full dose-treated plants had the highest yield values, but they were placed in the same statistical group with the half dose-treated plants. As compared to the full dose, yields in half dose and water treatments increase respectively by $18.7 \%$ and $71.8 \%$ in the $1^{\text {st }}$ harvest, by $10.0 \%$ and $70.8 \%$ in the $2^{\text {nd }}$ harvest and by $18.8 \%$ and 
$84.0 \%$ in the $3^{\text {rd }}$ harvest. With regard to yield values under interactions, the greatest yields in the $1^{\text {st }}$ and $3^{\text {rd }}$ harvests were obtained from $2^{\text {nd }}$ period $x$ full dose treatments and the greatest yields in the $2^{\text {nd }}$ harvests were obtained from $2^{\text {nd }}$ period $\mathrm{x}$ full dose treatments. Yields decreased in water treatments and the lowest yield values were obtained from water treatments in both periods (Table 2).

Table 2. Effects of different growing periods and nutrient solution concentrations on yield of harvests

\begin{tabular}{|c|c|c|c|c|}
\hline Period & $\begin{array}{l}\text { Nutrient } \\
\text { solution } \\
\text { concentration }\end{array}$ & $\begin{array}{c}\begin{array}{c}\text { Yield of } \\
\mathbf{1}^{\text {st }} \text { harvest } \\
\left(\mathrm{g} \mathrm{m}^{-2}\right)\end{array} \\
\end{array}$ & $\begin{array}{c}\begin{array}{c}\text { Yield of } \\
2^{\text {nd }} \text { harvest } \\
\left(\mathrm{g} \mathrm{m}^{-2}\right)\end{array} \\
\end{array}$ & $\begin{array}{c}\begin{array}{c}\text { Yield of } \\
\mathbf{3}^{\text {rd }} \text { harvest } \\
\left(\mathrm{g} \mathrm{m}^{-2}\right)\end{array} \\
\end{array}$ \\
\hline $1^{\text {st }}$ & & $1256.2 \mathrm{~b}$ & 733.9 a & \\
\hline \multirow[t]{4}{*}{$2^{\text {nd }}$} & & $1998.7 \mathrm{a}$ & $556.0 \mathrm{~b}$ & $953.3 \mathrm{a}$ \\
\hline & Full dose & $2083.1 \mathrm{a}$ & $788.2 \mathrm{a}$ & $1041.6 \mathrm{a}$ \\
\hline & Half dose & 1692.7 a & $709.1 \mathrm{a}$ & $845.9 \mathrm{a}$ \\
\hline & Water & $585.8 \mathrm{~b}$ & $229.9 \mathrm{~b}$ & $166.6 \mathrm{~b}$ \\
\hline \multirow[t]{3}{*}{$1^{\mathrm{st}}$} & Full dose & $1461.9 \mathrm{bc}$ & $911.1 \mathrm{a}$ & $820.9 \mathrm{bc}$ \\
\hline & Half dose & $1303.7 \mathrm{~cd}$ & $787.2 \mathrm{ab}$ & $655.0 \mathrm{c}$ \\
\hline & Water & $749.6 \mathrm{~cd}$ & $272.9 \mathrm{c}$ & $164.5 \mathrm{~d}$ \\
\hline \multirow[t]{3}{*}{$2^{\text {nd }}$} & Full dose & $2704.3 \mathrm{a}$ & $665.3 \mathrm{ab}$ & $1262.3 \mathrm{a}$ \\
\hline & Half dose & $2081.6 \mathrm{ab}$ & $631.1 \mathrm{~b}$ & $1036.7 \mathrm{ab}$ \\
\hline & Water & $422.0 \mathrm{~d}$ & $186.8 \mathrm{c}$ & $168.6 \mathrm{~d}$ \\
\hline Analysis & Period & * & * & * \\
\hline & Concentration & ** & ** & ** \\
\hline variance & Period $x$ Concentration & $*$ & * & * \\
\hline
\end{tabular}

Means within each column followed by the same letters are not significantly different according to Tukey test.

$*$ and **: significant at $0.01<P \leq 0.05$ and $P \leq 0.01$, respectively.

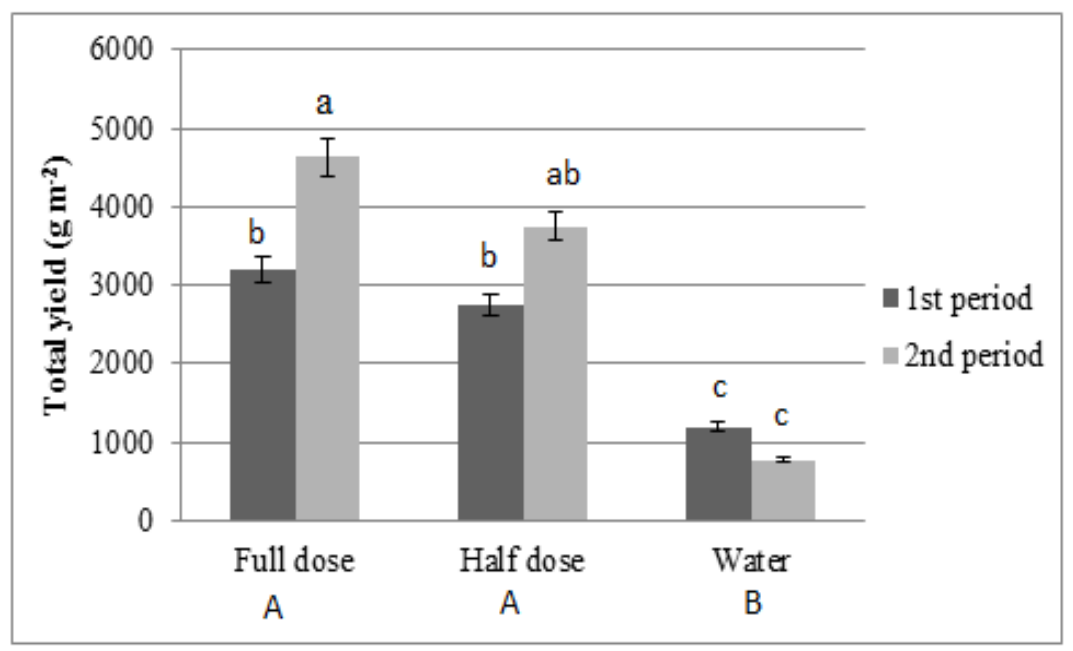

Figure 2. Total yields of treatment in both growing periods

Period: $0.01<P \leq 0.05$, Concentration: $P \leq 0.01$, Period $x$ Concentration: $0.01<P \leq 0.05$

Capital letters indicate main effects of nutrient solution concentration; small letters show interaction effects of period and concentration.

The total yield was $2613.3 \mathrm{~g} \mathrm{~m}^{-2}$ in the $1^{\text {st }}$ period and the value reached to $3508.0 \mathrm{~g}$ $\mathrm{m}^{-2}$ with $34.2 \%$ increase in the $2^{\text {nd }}$ period. Total yield values of full dose, half dose and water treatments were respectively measured as 3912.8, 3247.6 and $982.2 \mathrm{~g} \mathrm{~m}^{-2}$. As 
compared to full dose, $17.0 \%$ decrease was observed in half dose and $74.8 \%$ decrease was observed in water treatments. The greatest total yield was obtained from the $2^{\text {nd }}$ period $\mathrm{x}$ full dose interaction and it was followed by the $2^{\text {nd }}$ period $\mathrm{x}$ half dose which was placed in the same statistical group (Fig. 2). Of the total yield, 53.2\% was obtained from the $1^{\text {st }}$ harvest, $21.1 \%$ from the $2^{\text {nd }}$ harvest and $25.7 \%$ from the $3^{\text {rd }}$ harvest.

\section{Quality parameters}

Total chlorophyll contents were significantly influenced by the period, nutrient solution concentration and period $x$ concentration interaction. While the total chlorophyll content was $1.18 \mathrm{mg} \mathrm{g}^{-1}$ in the $1^{\text {st }}$ period, the value reached to $1.64 \mathrm{mg} \mathrm{g}^{-1}$ with $38.9 \%$ increase in the $2^{\text {nd }}$ period. Total chlorophyll contents did not significantly change in full dose and half dose treatments, but decreased by $12.5 \%$ in water treatments. The greatest chlorophyll content was obtained from the $2^{\text {nd }}$ period $x$ full dose interaction and it was followed by the $2^{\text {nd }}$ period $\mathrm{x}$ half dose interaction which was also placed in the same statistical group (Fig. 3).

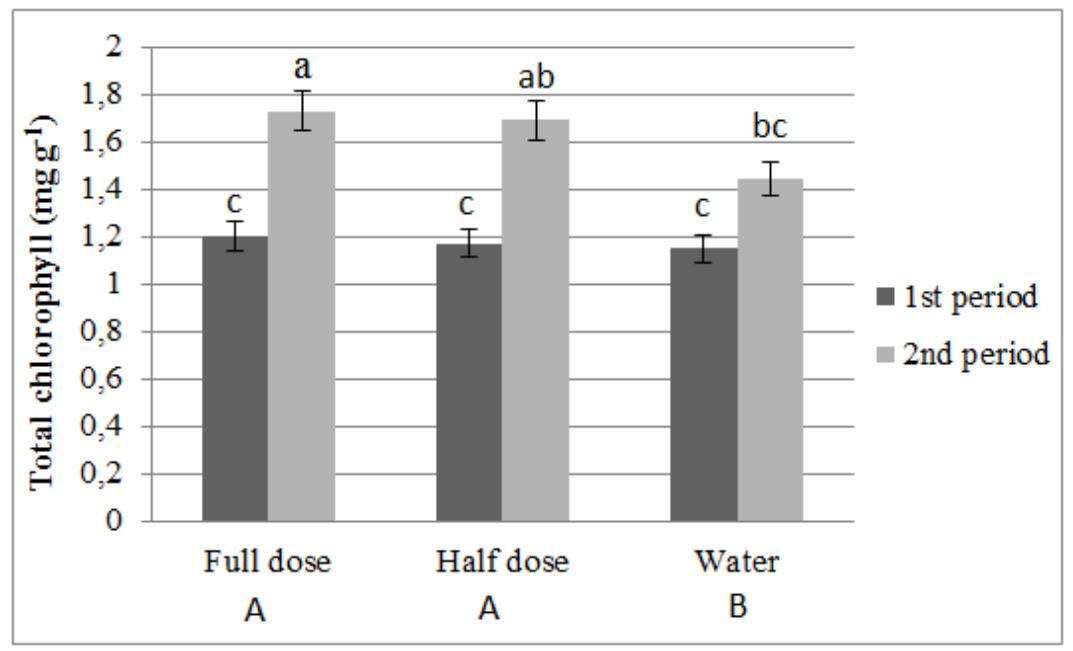

Figure 3. Effects of treatments on total chlorophyll content

Period: $P \leq 0.01$, Concentration: $0.01<P \leq 0.05$, Period $x$ Concentration: $0.01<P \leq 0.05$

Capital letters indicate main effects of nutrient solution concentration; small letters show interaction effects of period and concentration.

While periods did not have significant effects on leaf nitrate content, nutrient solution concentration had significant effects on nitrate contents. Leaf nitrate contents decreased with reduced nutrient solution concentration, but the differences between full dose and half dose treatments were not significant. As compared to half dose, leaf nutrient contents decreased by $9.1 \%$ in half dose treatments. The lowest leaf nitrate content was obtained from water treatments. Considering the interactions, the lowest leaf nitrate contents were obtained from water-treated plants of both periods. Significant differences were not observed in leaf nitrate contents of the other treatments (Fig. 4). 


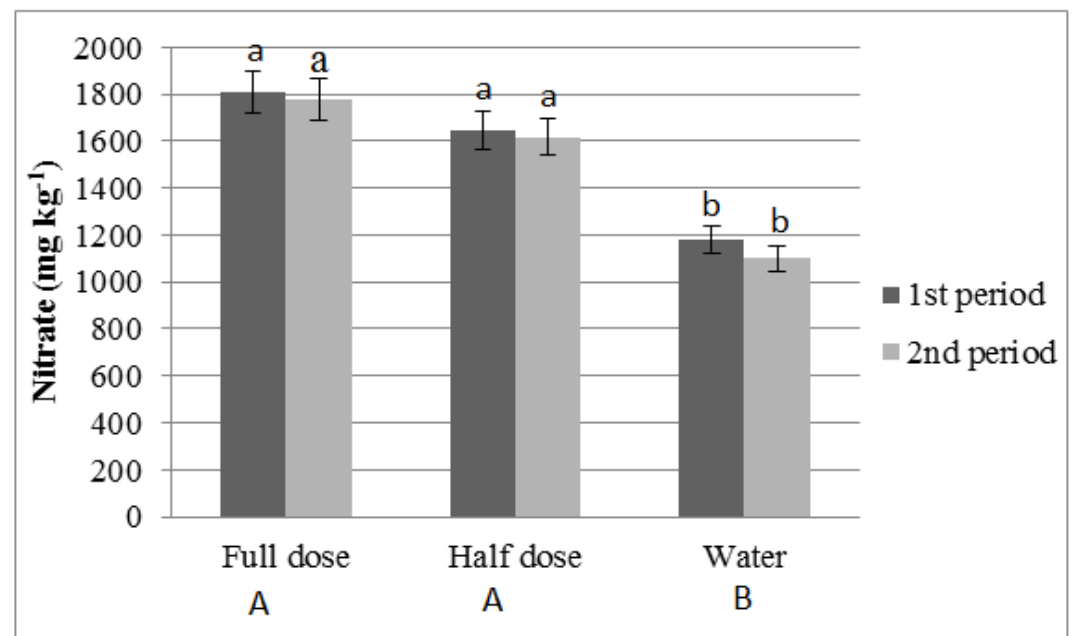

Figure 4. Effects of treatments on leaf nitrate content

Period: nonsignificant, Concentration: $0.01<P \leq 0.05$, Period $x$ Concentration: $P \leq 0.01$

Capital letters indicate main effects of nutrient solution concentration; small letters show interaction effects of period and concentration.

Vitamin C contents were also significantly influenced by the period, nutrient solution concentration and period $\mathrm{x}$ concentration interaction. As compared to the $1^{\text {st }}$ period, vitamin C content reached to $47.5 \mathrm{mg} 100 \mathrm{~g}^{-1}$ with $43.5 \%$ increase. Leaf vitamin $\mathrm{C}$ contents increased with decreasing nutrient solution concentration. Leaf vitamin $\mathrm{C}$ contents of full dose, half dose and water treatments were respectively measured as 29.8, 41.8 and $58.2 \mathrm{mg} 100 \mathrm{~g}^{-1}$. Under interaction, the greatest vitamin $\mathrm{C}$ content was obtained from the $1^{\text {st }}$ period $\mathrm{x}$ water and the $2^{\text {nd }}$ period $\mathrm{x}$ water treatments (Fig. 5).

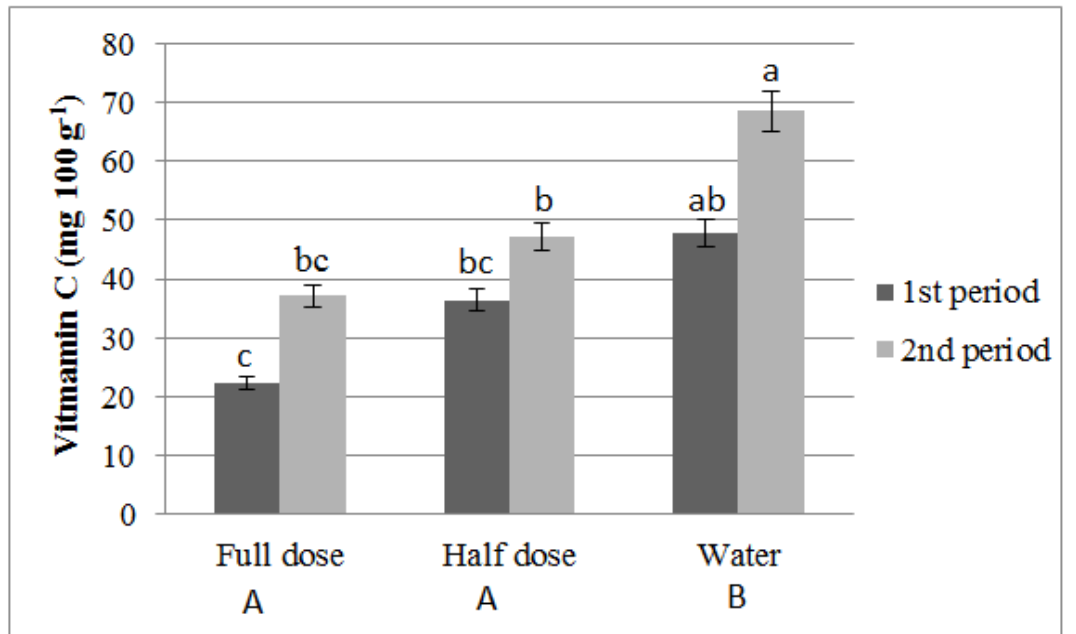

Figure 5. Effects of treatments on vitamin C content

Period: $P \leq 0.01$, Concentration: $P \leq 0.01$, Period $x$ Concentration: $P \leq 0.01$

Capital letters indicate main effects of nutrient solution concentration; small letters show interaction effects of period and concentration. 


\section{Leaf nutrient contents}

Growing period had significant effects on $\mathrm{P}$ and $\mathrm{Fe}$ contents and the values were greater in the $1^{\text {st }}$ period than in the $2^{\text {nd }}$ period. The effects of growing period on $\mathrm{N}, \mathrm{K}$, $\mathrm{Ca}$ and $\mathrm{Mg}$ contents were not found to be significant (Table 3).

Table 3. Effects of different growing periods and nutrient solution concentrations on leaf nutrient content

\begin{tabular}{|c|c|c|c|c|c|c|c|}
\hline Period & $\begin{array}{l}\text { Nutrient } \\
\text { solution concentration }\end{array}$ & $\begin{array}{l}\mathrm{N} \\
(\%)\end{array}$ & $\begin{array}{l}\mathbf{P} \\
(\%) \\
\end{array}$ & $\begin{array}{c}\mathbf{K} \\
(\%) \\
\end{array}$ & $\begin{array}{c}\mathrm{Ca} \\
(\%)\end{array}$ & $\begin{array}{l}\mathrm{Mg} \\
(\%)\end{array}$ & $\begin{array}{c}\mathrm{Fe} \\
\left(\mathrm{mg} \mathrm{kg}^{-1}\right)\end{array}$ \\
\hline $\begin{array}{l}1^{\text {st }} \\
2^{\text {nd }}\end{array}$ & & $\begin{array}{l}4.70 \\
4.61\end{array}$ & $\begin{array}{l}0.72 \mathrm{a} \\
0.60 \mathrm{~b}\end{array}$ & $\begin{array}{l}5.27 \\
5.27\end{array}$ & $\begin{array}{l}1.44 \\
1.40\end{array}$ & $\begin{array}{l}1.08 \\
1.00\end{array}$ & $\begin{array}{l}71.03 \mathrm{a} \\
60.35 \mathrm{~b}\end{array}$ \\
\hline \multirow{3}{*}{$2^{\text {nd }}$} & Full dose & $5.26 \mathrm{a}$ & $0.87 \mathrm{a}$ & $7.98 \mathrm{a}$ & $0.63 \mathrm{~b}$ & 1.02 & $80.45 \mathrm{a}$ \\
\hline & Half dose & $4.87 \mathrm{~b}$ & $0.88 \mathrm{a}$ & $6.16 \mathrm{~b}$ & $0.69 \mathrm{~b}$ & 1.01 & $76.45 \mathrm{a}$ \\
\hline & Water & $3.84 \mathrm{c}$ & $0.23 \mathrm{~b}$ & $1.68 \mathrm{c}$ & $2.93 \mathrm{a}$ & 1.09 & $40.18 \mathrm{~b}$ \\
\hline \multirow[t]{3}{*}{$1^{\mathrm{st}}$} & Full dose & $5.27 \mathrm{a}$ & $0.90 \mathrm{ab}$ & $7.84 \mathrm{ab}$ & $0.36 \mathrm{c}$ & 1.05 & $84.00 \mathrm{a}$ \\
\hline & Half dose & $4.90 \mathrm{~b}$ & $0.99 \mathrm{a}$ & $6.28 \mathrm{bc}$ & $0.39 \mathrm{c}$ & 1.07 & $82.40 \mathrm{a}$ \\
\hline & Water & $3.93 \mathrm{c}$ & $0.28 \mathrm{c}$ & $1.70 \mathrm{~d}$ & $3.55 \mathrm{a}$ & 1.12 & $46.70 \mathrm{c}$ \\
\hline \multirow[t]{3}{*}{$2^{\text {nd }}$} & Full dose & $5.25 \mathrm{a}$ & $0.84 \mathrm{~b}$ & $8.13 \mathrm{a}$ & $0.89 \mathrm{c}$ & 0.99 & $76.90 \mathrm{ab}$ \\
\hline & Half dose & $4.83 \mathrm{~b}$ & $0.77 \mathrm{~b}$ & $6.04 \mathrm{c}$ & $0.99 \mathrm{c}$ & 0.95 & $70.50 \mathrm{~b}$ \\
\hline & Water & $3.76 \mathrm{~d}$ & $0.19 \mathrm{c}$ & $1.66 \mathrm{~d}$ & $2.32 \mathrm{~b}$ & 1.06 & $33.65 \mathrm{~d}$ \\
\hline Analysis & Period & $n s$ & $*$ & $n s$ & $n s$ & $n s$ & $* *$ \\
\hline & Concentration & $* *$ & $* *$ & $* *$ & $* *$ & $n s$ & $* *$ \\
\hline variance & Period $x$ Concentration & $*$ & $*$ & $*$ & $* *$ & $n s$ & $*$ \\
\hline
\end{tabular}

Means within each column followed by the same letters are not significantly different according to Tukey test. ns, $*$ and $* *$ : nonsignificant, significant at $0.01<P \leq 0.05$ and $P \leq 0.01$, respectively.

Except for $\mathrm{Mg}$, nutrient solution concentration and period $\mathrm{x}$ concentration interaction had significant effects on all nutrients. $\mathrm{P}, \mathrm{Ca}$ and $\mathrm{Fe}$ contents of full and half dose treatments were not significantly different, but water treatments had significantly different values. $\mathrm{N}, \mathrm{P}, \mathrm{K}$ and $\mathrm{Fe}$ contents decreased, $\mathrm{Ca}$ contents increased with decreasing nutrient solution concentration. A similar case was also observed under interaction (Table 3).

\section{Plant water consumption}

Depending on seasonal temperature differences and length of growth periods, amount of water applied to treatments varied between $0.316-0.361 \mathrm{~L} \mathrm{plant}^{-1}$ in the $1^{\text {st }}$ period and between $0.387-0.434 \mathrm{~L}_{\text {plant }}{ }^{-1}$ in the $2^{\text {nd }}$ period. About $23.7 \%$ more water was applied to plants in the $2^{\text {nd }}$ period. Removed water quantity was greater in this period and plant water consumption was also $52.7 \%$ more as compared to the $1^{\text {st }}$ period. Effects of period and period $\mathrm{x}$ concentration interaction on plant water consumptions were significant, but nutrient solution concentrations did not have significant effects on water consumptions. Plant water consumption was $0.163 \mathrm{~L}_{\text {plant }}{ }^{-1}$ in the $1^{\text {st }}$ period and $0.249 \mathrm{~L} \mathrm{plant}^{-1}$ in the $2^{\text {nd }}$ period. Plant water consumptions of full dose, half dose and water treatments were respectively measured as $0.205,0.215$ and $0.197 \mathrm{~L}_{\text {plant }}{ }^{-1}$. Considering the interactions, the greatest plant water consumption was obtained from the $2^{\text {nd }}$ period $x$ half and full dose treatments (Fig. 6). 


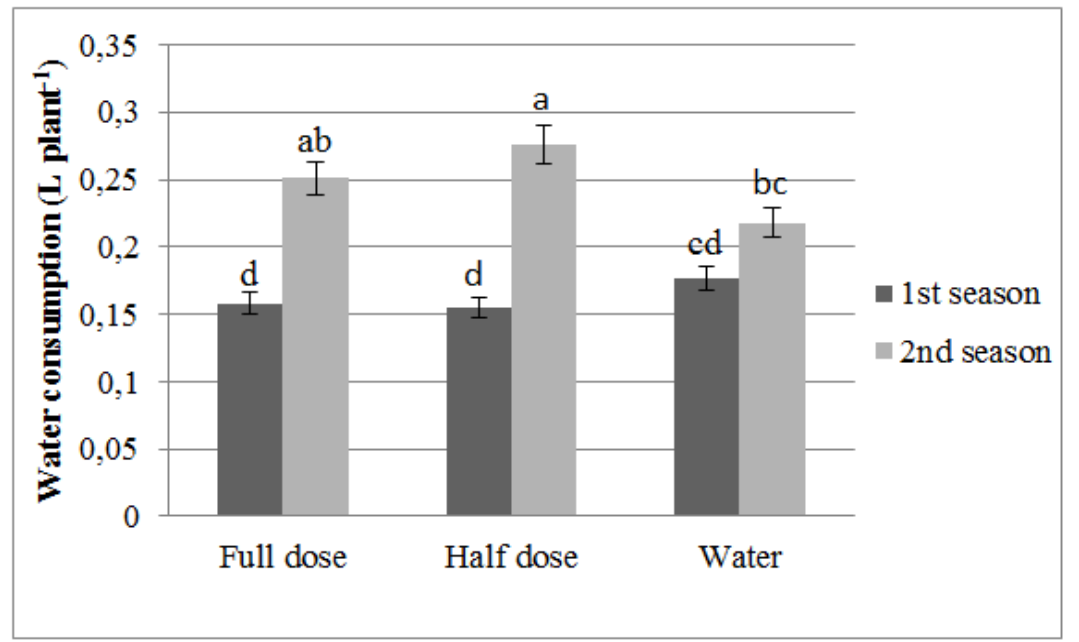

Figure 6. Plant water consumption under interaction effects of treatments Period: $P \leq 0.01$, Concentration: nonsignificant, Period $x$ Concentration: $P \leq 0.01$ Small letters show interaction effects of period and concentration.

\section{Nutrient solution EC and $\mathrm{pH}$ values}

Nutrient solution EC values of the $1^{\text {st }}$ period varied between $0.75-0.90 \mathrm{dS} \mathrm{m}^{-1}$ in water treatments, between 1.16-1.40 dS m${ }^{-1}$ in half dose treatments and between 1.56$1.75 \mathrm{dS} \mathrm{m}^{-1}$ in full dose treatments. The values were $0.8-1.0$ unit higher in the $2^{\text {nd }}$ period. Average EC of nutrient solution in full and half doses were 1.65 and $1.28 \mathrm{dS} \mathrm{m}^{-1}$ in the $1^{\text {st }}$ period and 2.51 and $2.0 \mathrm{dS} \mathrm{m}^{-1}$ in the $2^{\text {nd }}$ period, respectively.

Nutrient solution $\mathrm{pH}$ values were tried to be kept between 5.5 and 6.5 however, $\mathrm{pH}$ values of the $1^{\text {st }}$ period varied between 6.62-7.89 in water treatments, between 6.38-7.35 in half dose treatments and between 5.59-7.23 in full dose treatments. In the $2^{\text {nd }}$ period, $\mathrm{pH}$ values increased by $0.8-1.05$.

\section{Discussion}

Plant development and biomass values of both periods revealed that plant development decreased with decreasing nutrient solution concentration. Similar findings were also reported in previous studies carried out on spinach (Cocetta et al., 2007) and rocket (D'Anna et al., 2003). In present study, there were not significant differences between the full and half dose treatments, but full dose treatments had better plant growth and development because of higher nutrient content of solution provided to the plants however water-treated plants had the least development due to lack of nutrients sufficient for plant growth.

Plant development data also revealed that besides nutrient solution concentrations, indoor temperatures of the growing periods influenced plant growth and development (Alberici et al., 2008). High temperatures of the $2^{\text {nd }}$ period (average $19.8^{\circ} \mathrm{C}$ ) stimulated plant development (Alberici et al., 2008; Eşiyok, 2012).

In present study, root lengths exhibited a different trend from the other plant development parameters. Water-treated plants had longer root lengths and this may be result from plant instincts to release their roots to deeper portions of the growth medium to get plant nutrients under nutritional stress conditions (Taiz and Zeiger, 2008). 
However root dry matter was the highest in full dose in the $2^{\text {nd }}$ period which could be attributed either the nutrient concentration of solution or higher temperatures.

Hydroponic culture of miniature-leaf vegetables largely depends on environmental factors and species, but 3-6 weeks earliness is usually achieved with hydroponic culture compared with open field culture (Gonella et al., 2003 \& 2004; Cocetta et al., 2007; Conte et al., 2008). Harvest was performed in present study 4 weeks after seeding and 20 days after transplantation to water culture in the $2^{\text {nd }}$ period. In other word, an earliness was achieved with hydroponic culture (Eşiyok, 2012; Iannotti, 2017) due to higher temperatures, however in the $1^{\text {st }}$ period lower temperatures delayed harvests up to 8 weeks after the seeding (Alberici et al., 2008; Eşiyok, 2012).

In hydroponic cultures yield varies according to plant species and cultivars, growth period temperatures, number of plants per unit area (plant $\mathrm{m}^{-2}$ ), plant harvest lengths, growing periods, nutrient solution concentrations and number of harvests (D'Anna et al., 2003; Alberici et al., 2008; Jakse et al., 2013). For instance spinach yields for 1150 plant $\mathrm{m}^{-2}$ plant density and $10-15 \mathrm{~cm}$ harvest lengths was reported between $1130-1500 \mathrm{~g}$ $\mathrm{m}^{-2}$ (Cocetta et al., 2007) or between 832-1748 $\mathrm{g} \mathrm{m}^{-2}$ with $12 \mathrm{~cm}$ harvest lengths (Alberici et al., 2008). In present study, plant density was 957 plant $\mathrm{m}^{-2}$ and harvests were performed at plant heights of $10-15 \mathrm{~cm}$ and 3 harvests were performed in each treatment. As the average of two periods, the $1^{\text {st }}$ harvest yields at full dose, half dose and water treatments were respectively measured as 2083.1, 1692.7 and $585.8 \mathrm{~g} \mathrm{~m}^{-2}$. Total yields were respectively calculated as $3912.9,3247.7$ and $982.2 \mathrm{~g} \mathrm{~m}^{-2}$ which were greater than the earlier results reported for spinach in hydroponic culture (D'Anna et al., 2003; Vernieri et al., 2005; Cocetta et al., 2007; Alberici et al., 2008; RodriguezHidalgo et al., 2010; Duyar and Kılıç, 2016). Present findings revealed that spinach yields of hydroponic culture were also greater than the yield of soil-culture (Eşiyok, 2012). Water-treated plants had lower yield values than nutrient solution-treated (fertilized) plants. Such a finding indicated that very low amount of nutrients in the tap water and nitrogen coming from the nitric acid added to adjust element content and $\mathrm{pH}$ was not sufficient for plant growth and development particularly if the harvest period is extended.

In present study, yields decreased with decreasing nutrient solution concentrations. In previous studies, $20-50 \%$ decrease were reported with decreasing nutrient solution concentrations in rocket (Vernieri et al., 2005; Alberici et al., 2008; Duyar and Kıliç, 2016), spinach (Cocetta et al., 2007; Alberici et al., 2008) and lettuce (Alberici et al., 2008). Alberici et al. (2008) experimented 50\% and $25 \%$ reduced macro elements as compared to control (100\%) and reported varying decreases in yields of spinach, rocket and lettuce and recommended $25 \%$ reduction in micro nutrients. However, in our study full dose and half dose treatments were placed in the same statistical group. Thus, it was concluded that $50 \%$ reduction in macro element contents did not resulted in significant decreases in yields, thus could reliably be used in hydroponic spinach culture and provide significant savings in fertilizers and system costs.

Total chlorophyll contents varied between 1.15-1.73 $\mathrm{mg} \mathrm{g}^{-1}$ and present values comply with the earlier findings (Cocetta et al., 2007; Franco et al., 2011). Total chlorophyll contents were not influenced by nutrient solution concentrations (Cocetta et al., 2007; Alberici et al., 2008), but influenced by growth periods (Fallovo et al., 2009). Present chlorophyll contents were higher in the $2^{\text {nd }}$ period which could be attributed to higher temperatures (Popescu and Buruleanu, 2017). 
Leaf nitrate contents decreased with decreasing nutrient solution concentrations (Cocetta et al., 2007; Alberici et al., 2008; Fallovo et al., 2009; Duyar and K1lıç, 2016). Such a case can be explained with the decreased nitrate concentration of the plant tissues through using the nitrate already stored in vacuole in case of lower nitrate concentrations than the plant requirement (Okamoto et al., 2006; Tsay et al., 2006; Antonacci et al., 2007; Alberici et al., 2008). Besides genetic characteristics, growth period, light, temperature, growing conditions, fertilization and storage have also significant effects on plant nitrate accumulations (Premuzic et al., 2001; Frezza et al., 2005; Magnani et al., 2007; Kim and Ishii, 2007). In present study, leaf nitrate contents (1177.2-1811.9 $\mathrm{mg} \mathrm{kg}^{-1}$ ) also varied with the periods and nutrient solution concentrations which were in a harmony with previous research results (Cocetta et al., 2007; Alberici et al., 2008). European Commission Regulation No: 1258/2001 specify the maximum threshold value as $3500 \mathrm{mg} \mathrm{kg}^{-1}$ for spinach and lettuce (EUR-LEX, 2017). Present values were below this threshold value, thus did not exert any risks on human health.

Majority of leaf edible vegetables is a great source of vitamin C (Burrell and Ebright, 1940) and plant vitamin $C$ contents may vary with the growing period and cultural conditions (Eşiyok et al., 2006). Spinach vitamin C contents were reported as $19.4 \mathrm{mg}$ $100 \mathrm{~g}^{-1}$ by Cocetta et al. (2014), as between 25.0-71.0 mg $100 \mathrm{~g}^{-1}$ by Bergquist et al. (2007) and Çitak et al. (2010), as $48 \mathrm{mg} 100 \mathrm{~g}^{-1}$ by Bangash et al. (2011) and as 120.0 mg $100 \mathrm{~g}^{-1}$ by Fujiwara et al. (2005). Present values (22.42-68.60 mg $100 \mathrm{~g}^{-1}$ ) comply with those earlier ones. Nutrient solution concentration influenced vitamin $\mathrm{C}$ contents and increasing vitamin $\mathrm{C}$ contents were observed with decreasing nutrient solution concentrations (Duyar and Kılıç, 2016). Vitamin C content of full and half dose treatments were not significantly different. Higher vitamin $\mathrm{C}$ contents of water-treated plants were resulted from nutrient stress conditions since plants increase vitamin $\mathrm{C}$ contents under stress conditions (Munzuroğlu et al., 2000). Zhang et al. (2016) related such a case with increasing mioinocytol oxygenize enzyme activity in ascorbic acid biosynthesis and recycle and decreasing ascorbate oxidase and glutathione reductase enzyme activities. Ascorbic acid accumulation increases with decreasing $\mathrm{N}$ concentrations.

Leaf nutrient contents vary based on plant species and cultivars, growing period, production system, fertilization program, plant tissue and sampling time (Kacar and Inal, 2008). In present study leaf $\mathrm{N}$ contents varied between 3.76-5.27\%, P contents between $0.19-0.99 \%$, K contents between $1.66-8.13 \%$, Ca contents between 0.36$3.55 \%, \mathrm{Mg}$ contents between 0.95-1.125 and Fe contents between 33.7-84.0 mg kg-1. In both periods, leaf $\mathrm{N}, \mathrm{P}, \mathrm{K}$ and $\mathrm{Fe}$ contents decreased, but $\mathrm{Ca}$ contents increased with decreasing nutrient solution concentration. In IFA (1992) records, N, P, K, Ca, Mg and Fe contents of young spinach leaves harvested 40 days after plantation were respectively specified as $2.6 \%, 0.3 \%, 4.7 \%, 1.0 \%, 1.0 \%$ and $189 \mathrm{mg} \mathrm{kg}^{-1}$. Barlas et al. (2011) reported $\mathrm{N}$ contents of rocket leaves as between 2.94-5.23\% (average 4.32\%), $\mathrm{P}$ contents as between $0.12-0.27 \%$ (average $0.25 \%$ ), $\mathrm{K}$ contents between $3.99-5.98 \%$ (average $5.13 \%$ ), Ca contents between $2.20-3.55 \%$ (average $2.95 \%$ ), $\mathrm{Mg}$ contents between $0.33-0.79 \%$ (average $0.58 \%$ ) and $\mathrm{Fe}$ contents between $183.3-776.9 \mathrm{mg} \mathrm{kg}^{-1}$ (average $350 \mathrm{mg} \mathrm{kg}^{-1}$ ). Present $\mathrm{N}, \mathrm{Ca}$ and $\mathrm{Fe}$ values of floating culture system were lower, but $\mathrm{P}, \mathrm{K}$ and $\mathrm{Mg}$ contents were higher than those earlier findings. High nutrient contents may be related to sink effect of young leaves under existence of high nutrient concentrations (Gonnella et al., 2004). 
The amount of water applied to plants was greater in the $2^{\text {nd }}$ growing period because of higher temperatures of the period. Since the system is a closed system, only the nutrient solution left at the end of the period was removed. Nutrient solution concentrations did not influence amount of water applied. Plant water consumption was the greatest in half dose treatments and the least in water treatments. However, the differences in water consumptions were not significant. Similar with the present findings, Duyar and Kılıç (2016) also reported higher water consumptions for half dose treatments in rocket and parsley grown in floating water culture in autumn and spring seasons and researchers indicated higher water consumption values in spring season.

Since plants are cultured in closed soilless systems, $\mathrm{pH}, \mathrm{EC}$ and dissolved oxygen levels of the system should be carefully adjusted (Gonella et al., 2003). Potential EC and $\mathrm{pH}$ problems can be eliminated with a proper nutrient solution and dissolved oxygen problems can be eliminated through proper aeration of the system (Tesi et al., 2003; Lenzi et al., 2011).

\section{Conclusion}

Recent researches about floating hydroponic cultures mostly focused on practices to reduce system costs (seed bed ambient, ambient quantity). It is quite significant to find cheap and easily supplied seed germination media. In present study, peat (Klassman TS1) with quite high germination performance and can be easily supplied from the markets was used (Rodriguez-Hidalgo et al., 2010; Jakse et al., 2013) and a successful culture was achieved. Cocetta et al. (2007) used perlite in hydroponic study and reported yields as between $1.1-1.5 \mathrm{~kg} \mathrm{~m}^{-2}$. Such values were lower than the value obtained from peat. Researches are still going on about different substrate materials. Amount of growing medium per seedling tray is also an important factor in reducing system costs. Jakse et al. (2013) achieved better outcomes from rocket hydroponic study with small-size cells, thus with greater plant density (160 cell seedling trays, 2000 seed $\mathrm{m}^{-2}$ ). Further research is needed about optimum cell sizes for different species. In present study, $17 \mathrm{cc}$ seedling trays with 210 cells $\left(957\right.$ plant $\mathrm{m}^{-2}$ ) were used and a successful culture was achieved. However, there is still a need for further research on seedling tray shapes (lined-trays), trays cell sizes and plant densities.

Considering entire results of the present study, it was concluded that (1) winter lettuce prescription ( $\mathrm{mg} \mathrm{L}^{-1}: \mathrm{N} 150, \mathrm{P} 50, \mathrm{~K} 150, \mathrm{Ca} 150, \mathrm{Mg} \mathrm{50}, \mathrm{Fe} \mathrm{5.0,} \mathrm{Mn} \mathrm{0.50,} \mathrm{Zn}$ $0.05, \mathrm{~B} 0.50, \mathrm{Cu} 0.03$, Mo 0.02) could reliably be used for hydroponic spinach culture without any losses in yield and quality; (2) $50 \%$ macro nutrients reduced half dose (mg $\mathrm{L}^{-1}: \mathrm{N} 75, \mathrm{P} 25, \mathrm{~K} 75, \mathrm{Ca} 75, \mathrm{Mg} 25, \mathrm{Fe} 5.0$, Mn 0.50, Zn 0.05, B 0.50, Cu 0.03, Mo 0.02 ) could be used successfully in hydroponic spinach culture since the yields of half dose treatments were not significant different from the full dose treatments and half dose reduced leaf nitrate contents. In this way, significant savings could be achieved in fertilizer costs; (3) spinach culture should be performed under optimum climate conditions for high yield, quality and earliness since temperature is a limiting factor for growth and development of vegetables, yields are significantly influenced by low temperatures. However further researches are needed optimization for fast and continuous production at larger scale. 
Acknowledgements. This study was financially supported by the Ege University, Faculty of Agriculture, Agency of Scientific Research Projects under Grant No 2017-ZRF-001.

\section{REFERENCES}

[1] Alberici A., Quattrini E., Penati, M., Martinetti, L., Gallina, P.M., Ferrante, A., Schiavi, M. (2008): Effect of the reduction of nutrient solution concentration on leafy vegetables quality grown in floating system. - Acta Horticulturae 801: 1167-1175.

[2] Antonacci, S., Maggiore, T., Ferrante, A. (2007): Nitrate metabolism in plants under hypoxic and anoxic conditions. - Plant Stress 1: 136-141.

[3] Arnon, D.I. (1949): Copper enzymes in isolated chloroplasts. Polyphenoloxidase in Beta vulgaris. - Plant Physiology 24(1): 1-15.

[4] Bangash, J.A., Arif, M., Khan, F., Khan, F., Amin-Ur, R., Iqbal, H. (2011): Proximate composition, minerals and vitamins content of selected vegetables grown in Peshawar. Journal of the Chemical Society of Pakistan 33(1): 118-122.

[5] Barlas, N.T., İrget, M.E., Tepecik, M. (2011): Mineral content of the rocket plant (Eruca sativa). - African Journal of Biotechnology 10(64): 14080-14082.

[6] Bergquist, S.A., Gertsson, U.E., Nordmark, L.Y., Olsson, M.E. (2007): Ascorbic acid, caretenoids, and visual quality of baby spinach as affected by shade netting and postharvest storage. - Journal of the Agricultural Food Chem 55: 8444-8451.

[7] Bilalis, D., Kanatas, P., Patsiali, S., Konstantas, A., Akoumianakis, K. (2010): Comparison between conventional and organic floating systems for lettuce and tomato (Lactuca sativa and Lycopersicon esculentum) seedling production. - Journal of Food, Agriculture \& Environment 7(2): 623-628.

[8] Brandenberger, L., Cavins, T., Payton, M., Wells, L., Johnson, T. (2007): Yield and quality of spinach cultivars for greenhouse production in Oklahoma. HortTechnology 17(2): 269-272

[9] Burrell, R.C., Ebright V.R. (1940): The vitamin C content of fruits and vegetables. Journal of Chemical Education 17(4): 180-182.

[10] Carrasco, G., Martinez A.C., Marquez, O., Osorio, D. (2003): Vegetable seedlings grown in a float system. - Acta Horticulturae 614: 241-245.

[11] Carrasco, G., Gajardo, J.M., Álvaro, J.A., Urrestarazu, M. (2011): Rocket production (Eruca sativa Mill.) in a floating system using peracetic acid as oxygen source compared with subsrate culture. - Journal of Plant Nutrition 34: 1397-1401.

[12] Cataldo, D.A., Haaron, M., Schrader, L.F., Youngs, V.L. (1975): Rapid colormetric determination of nitrate in plant-tissue by nitration of salicylic-acid. - Communications in Soil Science and Plant Analysis 6: 71-80.

[13] Cocetta, G., Quattrini, E., Schiavi, M., Martinetti, L., Spinardi, A., Ferrante, A. (2007): Nitrate and sucrose content in fresh-cut leaves of spinach plants grown in floating system. - Agricultural Medicine 137: 79-85.

[14] Cocetta, G., Baldassarre, V., Spinardi, A., Ferrante, A. (2014): Effect of cutting on ascorbic acid oxidation and recycling in fresh-cut baby spinach (Spinacia oleracea L.) leaves. - Postharvest Biology and Technology 88: 8-16.

[15] Conte, A., Conversa, G., Scrocco, C., Brescia, I., Laverse, J., Elia, A., Del Nobile, M.A. (2008): Influence of growing periods on the quality of baby spinach leaves at harvest and during storage as minimally processed produce. - Postharvest Biology and Technology 50(2-3): 190-196.

[16] Çıtak, S., Sönmez, S., Koçak, F., Yaşin, S. (2010): Effects of vermicompost and farmyard manure applications on spinach (Spinacia oleracea) Vitamin $\mathrm{C}$ and nitrate content (in Turkish). - Journal of Ege University Faculty of Agriculture Special issue: 653-658.

[17] D'Anna, F., Miceli, A., Vetrano, F. (2003): First results of floating system cultivation of Eruca sativa L. - Acta Horticulturae 609: 361-364. 
[18] Duyar, H., Kılıç, C.C. (2016): A research on production of rocket and parsley in floating system. - Journal of Agricultural Science 8(7): 54-60.

[19] EUR-LEX (2017): Commission Regulation (EU) No 1258/2011 of 2 December 2011 amending Regulation (EC) No 1881/2006 as regards maximum levels for nitrates in foodstuff. - http://eur-lex.europa.eu/legal-content/EN/TXT/HTML/?uri=CELEX :32011R $1258 \&$ from $=\mathrm{EN}$ (Accessed date: 15.08.2017)

[20] Eşiyok, D., Ongun, A.R., Bozokalfa, M.K., Tepecik, M., Okur, B., Kaygısız, T. (2006): Organic rocket production (in Turkish). $-6^{\text {th }}$ National Vegetable Symposium, September 19-22, 2006, Kahramanmaraş, Turkey.

[21] Eşiyok, D. (2012): Production of Cool and Warm Season Vegetables (in Turkish). Meta Press, İzmir/Turkey, $404 \mathrm{p}$.

[22] Fallovo, C., Rouphael, Y., Rea, E., Battistelli, A., Colla, G. (2009): Nutrient solution concentration and growing season effect yield and quality of Lactuca sativa L. var. acephala in floating raft culture. - Journal of the Science of Food and Agriculture 89: 1682-1689.

[23] Fernández, J.A., Navarro, A., Vicente, M.J., Peñapareja, D., Plana, V. (2008): Effect of seed germination methods on seedling emergence and earliness of purslane (Portulaca oleracea L.) cultivars in a hydroponic floating system. - Acta Horticulturae 782: 207212.

[24] Franco, J.A., Cros, V., Vicente, M.J., Martinez-Sanchez, J.J. (2011): Effects of salinity on the germination, growth, and nitrate contents of purslane (Portulaca oleracea L.) cultivated under different climatic conditions. - Journal of Horticultural Science \& Biotechnology 86(1): 1-6.

[25] Frezza, D., León, A., Logegaray, V., Chiesa, A., Desimone, M., Diaz, L. (2005): Soilless culture technology for high quality lettuce. - Acta Horticulturae 697: 43-48.

[26] Fontana, E., Tibaldi, G., Nicola, S. (2010): Effect of the nutrient solution and shelf-life conditions on the essential oil profile of minimally processed dill (Anethum graveolens L.) grown in a soilless culture system. - Acta Horticulturae 877: 135-142.

[27] Fujiwara, T., Kumakura, H., Ohta, S., Yoshida, Y., Kameno, T. (2005): Seasonal variation of L-ascorbic acid and nitrate content of commercially available spinach. Horticultural Researches 4(3): 347-352.

[28] Gonnella, M., Serio, F., Conversa, G., Santamaria, P. (2003): Yield and quality of lettuce grown in floating system using different sowing density and plant spatial arrangements. Acta Horticulturae 614: 687-692.

[29] Gonnella, M., Serio, F., Conversa, G., Santamaria, P. (2004): Production and nitrate content in Lamb's lettuce grown in floating system. - Acta Horticulturae 644: 61-68.

[30] Gül, A. (2008): Soiless Culture (in Turkish). - Hasad Press, İstanbul/Turkey, 144 p.

[31] Hoagland, D.R., Aron, D.I. (1950): The water culture method for growing plants without soil. - California Agricultural Experiment Station, Circular 347, Berkley, CA.

[32] Iannotti, M. (2017): How to grow sorrel: Tips and insights to growing and using sorrel. (https://www.thespruce.com/how-to-grow-sorrel-4121351), Access date: 16.08.2017

[33] IFA (1992): IFA World Fertilizer Use Manual. - International Fertilizer Industry Association, Paris, France. 632 p.

[34] Jakse, M., Hacin, J., Marsic, K.N. (2013): Production of rocket (Eruca sativa Mill.) on plug trays and on a floating system in relation to reduced nitrate content. - Acta Agriculturae Slovenica 101(1): 59-68.

[35] Kaçar, B., İnal, A. (2008): Plant Analysis (in Turkish). - Nobel Press, Ankara/Turkey, 892 p.

[36] Kara, E. (1993): Nitrate accumulation in vegetables (in Turkish). - Ecology 7: 10-13.

[37] Kim, S.J., Ishii, G. (2007): Effect of storage temperature and duration on glucosinolate, total vitamin $\mathrm{C}$ and nitrate contents in rocket salad (Eruca sativa Mill.). - Journal of the Science of Food and Agriculture 87: 55-62. 
[38] Ko, S.H., Park, J.H., Kim, S.Y., Lee, S.W., Chun, S.S., Park, E. (2014): Antioxidant effects of spinach (Spinacia oleracea L.) supplementation in hyperlipidemic rats. Preventive Nutrition and Food Science 19(1): 19-26.

[39] Lenzi, A., Baldi, A., Tesi, R. (2011): Growing spinach in a floating system with different volumes of aerated or nonaerated nutrient solution. - Advances in Horticultural Science 25(1): 21-25.

[40] Magnani, G., Filippi F., Borghesi, E. (2007): Impact of sunlight spectrum modification on yield and quality of ready-to-use lettuce and rocket salad grown on floating system. Acta Horticulturae 801:163-169.

[41] Morgan, L. (1999): Hydroponic Lettuce Production. - Casper Productions, Narrabeen, NSW, Australia.

[42] Munzuroğlu, Ö., Karataş, F., Gür, N. (2000): A Study of the levels of vitamins A, E and C and selenium in rhubarb (Rheum ribes L.) (in Turkish). - Turkish Journal of Biology 24: 397-404.

[43] Nicola, S., Hoeberechts, J., Fontana, E. (2005): Comparison between traditional and soilless culture systems to produce rocket (Eruca sativa) with low nitrate content. - Acta Horticulturae 697: 549-555.

[44] Nicola, S., Hoeberechts, J., Fontana, E. (2007): Ebb-and-flow and floating systems to grow leafy vegetables: a review for rocket, corn salad, garden cress and purslane. - Acta Horticulturae 747:585-593.

[45] Okamoto, M., Kumar, A., Li, W., Wang, Y., Siddiqi, M.Y., Crawford, N.M., Glass, D.M.A. (2006): High-affinity nitrate transport in roots of arabidopsis depends on expression of the NAR2-Like gene Atnrt3.1. - Plant Physiology 140: 1036-1046.

[46] Özdestan, Ö., Üren, A. (2010): Nitrate and nitrite in foods (in Turkish). - Academic Food Journal 8(6): 35-43.

[47] Pearson, D. (1970): The Chemical Analysis of Foods. - Chemical Publishing Co Inc, New York, USA.

[48] Popescu, E.C., Buruleanu, C.L. (2017): Heat degradation kinetics of the chlorophyll from spinach and its correlation with the reflection spectra. - Revista de Chimie (the Chemistry Magazine) 68(4): 830-834.

[49] Premuzic, Z., Gárate, A., Bomilla, I. (2001). Yield and quality of greenhouse lettuce as affected by form of $\mathrm{N}$ fertiliser and light supply. - In: Horst Walter, W.J., Sattelmacher B., Schmidhalter U., Schubert S., Wirén N. Von (eds) Plant Nutrition (Developments in Plant and Soil Science, Volume 92), Food Security and Sustainability of AgroEcosystem, Springer, Dordrecht, p. 300-301.

[50] Resh, H.M. (1998): Hydroponic Food Production. - Woodbrigde Press Publishing Company, Santa Barbara, CA.

[51] Rodríguez-Hidalgo, S., Artés-Hernández, F., Gómez, P.A., Fernández, J.A., Artés, F. (2010): Quality of fresh-cut baby spinach grown under a floating trays system as affected by nitrogen fertilization and innovative packaging treatments. - Journal of the Science of Food and Agriculture 90: 1089-1097.

[52] Taiz, L., Zeiger, E. (2008): Plant Physiology (in Turkish, Translate: İsmail Türkan). Palme Press, Ankara/Turkey, 690 p.

[53] Tannenbaum, S.R., Correa, P. (1985): Nitrate and gastric cancer risks. - Nature 317: 675676.

[54] Tesi, R., Lenzi, A., Lombardi, P. (2003): Effect of salinity and oxygen level on lettuce grown in a floating system. - Acta Horticulturae 609: 383-387.

[55] Tomasi, N., Roberto, P., Luisa, D.C., Cortella, G., Terzano, R., Mimmo, T., Scampicchio, M., Cesco, S. (2015): New 'solutions' for floating cultivation system of ready-to-eat salad: A review. - Trends in Food Science \& Technology 46: 267-276.

[56] Tsay, Y.F., Chiu, C.C., Tsai, C.B., Ho, C.H., Hsu, P.K. (2006): Nitrate transporters and peptide transporters. - Federation of European Biochemical Societies (FEBS) Letters 581: 2290-2300. 
[57] Van Der Boon, J., Steenhuizen, J.W., Steingrover, E.G. (1990): Growth an nitrate concentration of lettuce as affected by total nitrogen and chloride concentration, $\mathrm{NH}_{4} / \mathrm{NO}_{3}$ ratio and temperature of the recirculating nutrient solution. - Journal Horticulture Science 65: 309-321.

[58] Vernieri, P., Borghesi, E., Ferrante, A., Magnani, G. (2005): Application of biostimulants in floating system for improving rocket quality. - Journal of Food, Agriculture and Environment 3(3-4): 86-88.

[59] Yadav, R.K., Kalia, P., Kumar, R., Jain, V. (2013): Antioxidant and nutritional activity studies of green leafy vegetables. - International Journal of Agriculture and Food Science Technology 4(7): 707-712.

[60] Zhang, X., Yu, H.J., Zhang, X.M., Yang, X.Y., Zhao, W.C., Li, Q., Jiang, W.J. (2016): Effect of nitrogen deficiency on ascorbic acid biosynthesis and recycling pathway in cucumber seedlings. - Plant Physiology and Biochemistry 108: 222-230. 